\title{
Silicon application and related changes in soil bacterial community dynamics reduced ginseng black spot incidence in Panax ginseng in a short-term study
}

Meijia Li, Qiuxia Wang, Zhengbo Liu, Xiaoxi Pan and Yayu Zhang*

\begin{abstract}
Background: This study analyzed the effect of silicon (Si) application on the occurrence of ginseng black spot caused by Alternaria panax. We explored the differences in soil physical and chemical factors and microbial community structure following Si application as well as the key factors that affected the occurrence of ginseng black spot in soil. Potted Panax ginseng plants were used to assess the effect of Si treatment on ginseng black spot. Soil physical and chemical properties were comprehensively analyzed. Bacterial communities were analyzed using Illumina HiSeq sequencing targeting the 165 rRNA gene.

Results: After inoculation with A. panax, the morbidity (and morbidity index) of ginseng with and without Si was 52\% (46) and 83\% (77), respectively. Soil physical and chemical analysis showed that under the ginseng black spot inoculation, bacterial communities were mainly affected by $\mathrm{pH}$ and available potassium, followed by ammonium nitrogen and available Si. NMDS and PLS-DA analyses and the heat maps of relative abundance revealed that $\mathrm{Si}$ application elevated the resistance of ginseng black spot as regulated by the abundance and diversity of bacterial flora in rhizosphere soils. Heatmap analysis at the genus level revealed that A. panax + Si inoculations significantly increased the soil community abundance of Sandaracinus, Polycyclovorans, Hirschia, Haliangium, Nitrospira, Saccharothrix, Aeromicrobium, Luteimonas, and Rubellimicrobium and led to a bacterial community structure with relative abundances that were significantly similar to that of untreated soil.
\end{abstract}

Conclusions: Short-term Si application also significantly regulated the structural impact on soil microorganisms caused by ginseng black spot. Our findings indicated that Si applications may possibly be used in the prevention and treatment of ginseng black spot.

Keywords: Alternaria panax, Silicon, Ginseng black spot, Soil bacterial community, Panax ginseng, Illumina HiSeq sequencing

\section{Background}

Ginseng black spot, caused by Alternaria panax Whetz, is a common soil-borne disease and one of the most serious diseases affecting the above-ground parts, especially the leaves, of Panax ginseng. This pathogen is distributed widely in the Changbai Mountains of China and other ginseng production regions, and accounts for more than $20-30 \%$ of the annual incidence, which is very common

\footnotetext{
* Correspondence: zyy1966999@126.com

Institute of Special Wild Economic Animals and Plants, Chinese Academy of Agriculture Sciences, Changchun 130112, People's Republic of China
}

in cultivated and wild ginseng. Alternaria panax infestation may lead to $10-20 \%$ yield loss of the total crop. Infection first appears as elongated reddish to dark brown crevices in the infected areas. In seedlings, the stems are gradually girdled and thus collapse, resulted in damping-off [1]. In older plants, foliar infections appear later in summer, characterized by rapidly enlarging dark brown necrotic spots (circular, ellipsoid, or wedgeshaped) surrounded by chlorotic margins.

Silicon ( $\mathrm{Si}$ ) has been demonstrated to play an important role in enhancing plant resistance to disease. Si deposition

(c) The Author(s). 2019 Open Access This article is distributed under the terms of the Creative Commons Attribution 4.0 International License (http://creativecommons.org/licenses/by/4.0/), which permits unrestricted use, distribution, and 
has been suggested to create a physical barrier along cell walls and prevent fungal penetration into the plant [2]. Additional studies have indicated that $\mathrm{Si}$ is related to plant-pathogen interactions for the control in diseases in different plant species [3], and aids in the enhancement of plant resistance against disease caused by viruses, fungi, bacteria, and nematodes. Recently, it was suggested that the deposition of $\mathrm{Si}$ in the apoplast may prevent fungal effectors from entering the target cells, thus altering the development of the pathogens [4]. Another recently study showed that $\mathrm{Si}$ treatment conferred an effective protection of soybean plants against Phytophthora sojae in a hydroponic experiment [5]. Agricultural soil productivity largely depends on microbial diversity and community composition, which significantly affects plant growth and crop quality [6]. The homeostasis of the soil microbial community can suppress pathogens and promote plant growth [7]. Plant-microbe interactions remodel the complex biological and ecological processes in soil, where roots are influenced by the rhizosphere [8]. Many studies have assessed the effect of Si on plant-microbe interactions and have demonstrated that $\mathrm{Si}$ enhances plant resistance to pathogens by activating defense reactions $[9,10]$. Recently, a pot experiment demonstrated that $\mathrm{Si}$ addition decreased the concentrations of water-soluble and exchangeable arsenic in soil and, therefore, decreased the bioavailability of red soil arsenic in Panax notoginseng [11].

The present study, therefore, aimed to investigate if $\mathrm{Si}$ treatment would enhance the resistance of ginseng against $A$. panax. The study objectives were to evaluate the effect of $\mathrm{Si}$ on the prevention and treatment of ginseng black spot and to analyze the interaction between soil properties and plant growth responses. Further objectives were to determine the changes in the dynamics, i.e., the structure, composition, and abundance, of the soil microbial community in response to infection with A. panax and treatment with Si to determine the underlying factors that may influence the quantity and composition of soil bacteria.

\section{Results}

\section{Disease index and incidence and plant weights}

Figure 1 shows the phenotypic differences in leaves of $P$. ginseng in 9 dpi among treatment groups: Control, A, AS, and S. Significant differences were observed in the severity of $A$. panax infections under $\mathrm{Si}$ treatment (Fig. 1). As shown in Fig. 1, no effect of $\mathrm{Si}$ on biomass was observed compared to the Control group. The differences between Control plants and group $\mathrm{S}$ plants were not obvious, however, group AS plants were obviously healthier than group A plants (Fig. 1). The first symptom of leaf spots appeared soon (3 days) after post inoculation (dpi), followed by stunting and blight within a few days. As shown in Table 1, Si treatment significantly reduced the disease incidence and disease index of ginseng black spot.

There was no significant difference in dry weight among non-inoculated (pathogen) plants: Control plants $(1.12 \pm 0.81 \mathrm{~g})$ and group $\mathrm{S}$ plants $(1.23 \pm 0.59 \mathrm{~g})$. However, the plant dry weight was significantly reduced in group A plants. Apparently, Si treatment resulted in significantly heavier plants (Table 2). After 9 days posttreatment, the fresh weight of group AS plants was 15\% higher than that of group A plants (Table 3).
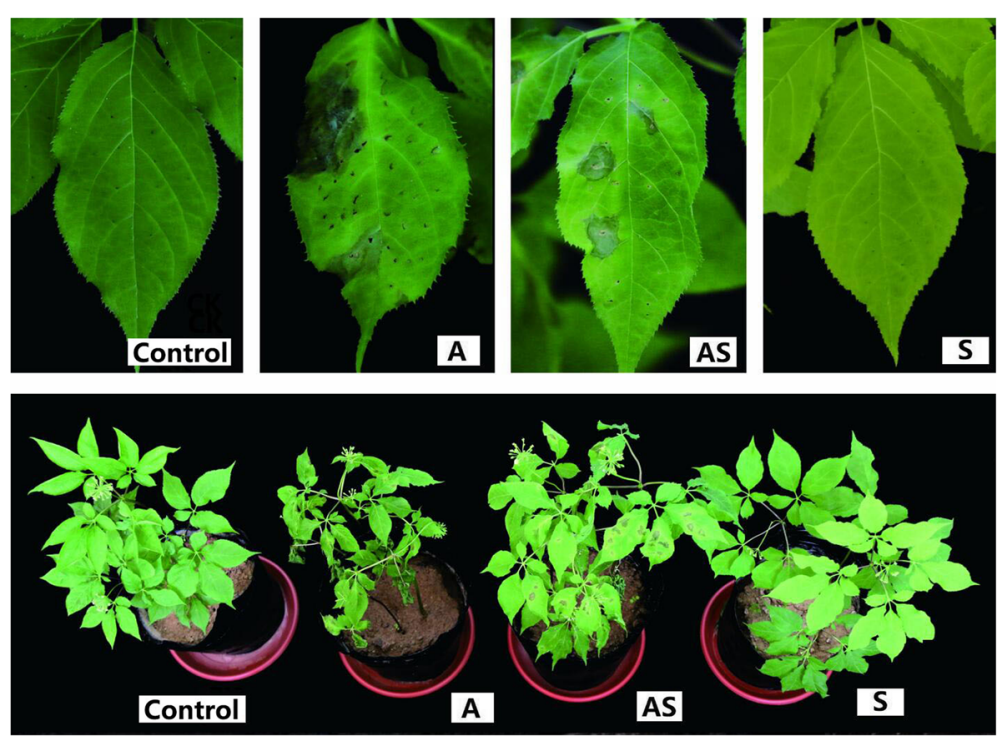

Fig. 1 The effect in different treatments of soil. Abbreviations: CK, ginseng control plants; A, plants only inoculated with A. panax; AS, plants inoculated with A. panax $+\mathrm{Si}$; S, plants only inoculated with $\mathrm{Si}$ 
Table 1 Effect of silicon application on the disease incidence and disease index of ginseng black spot

\begin{tabular}{lll}
\hline Treatment & Disease incidence (\%) & Disease index \\
\hline A & $83.5 \pm 6.5 \mathrm{a}$ & $77.8 \pm 7.5 \mathrm{a}$ \\
AS & $52.6 \pm 9.7 \mathrm{~b}$ & $46 \pm 5.6 \mathrm{~b}$ \\
\hline
\end{tabular}

Abbreviations: A, A.panax inoculated ginseng; AS, Silicon inoculated in soil with $A$. panax infection

\section{Soil properties and plant growth responses}

Soil properties are presented in Table 4. A one-way ANOVA showed that the treatments significantly recovered the soil property parameters from disease treatment $(P<0.05)$. (Table 4). The $\mathrm{pH}$ value of the Control soil samples was $\sim 7.39$. Compared with the Control group, the soil $\mathrm{pH}, \mathrm{NO}_{3}{ }^{-}-\mathrm{N}$, and $\mathrm{NH}_{4}{ }^{+}-\mathrm{N}$ were significantly reduced in Group A $(P<0.05)$. In contrast, the ratio of available $\mathrm{P}$ and available $\mathrm{K}(P<0.05)$ were significantly increased. Furthermore, AS significantly increased the soil $\mathrm{pH}$, and $\mathrm{NO}_{3}{ }^{-}-\mathrm{N}$ and $\mathrm{NH}_{4}{ }^{+}-\mathrm{N}$ contents $(P<0.05)$, and significantly reduced the ratio of available $\mathrm{P}$ and available $\mathrm{K}(P<0.05)$ compared to the A treatment, i.e., without $\mathrm{Si}(P<0.05)$. No significant differences in the above-mentioned nutrients, except available $\mathrm{Si}$, was detected between group $\mathrm{S}$ and Control.

\section{Analysis of bacterial composition and diversity of soil bacterial community structure based on 16S rRNA gene sequencing}

Bacteria-targeted regions were completely amplified by PCR and fully sequenced for all soil samples. The raw sequence libraries were screened to remove reads that originated from sequencing noise or putative chimeric sequences. Using the 12 soil samples from the different treatments, a total of 815,609 valid $16 \mathrm{~S}$ rDNA sequences were obtained by filtering and processing according to a $97 \%$ similarity. Variation of a single soil sample ranged from 56,510 to 76,384 sequences, and the above sequences were retained for further analysis.

The effective sequence number and OTU number of each group of samples did not significantly differ between the treatment groups and the Control group, as shown in Table 5 . The sequencing coverage of samples ranged from 98.5 to $98.6 \%$. After sample diversity (alpha diversity) analysis, the indexes reflecting the abundance and diversity of microbial communities were calculated,

Table 2 The fresh weight and dry weight of the ginseng after different treatments

\begin{tabular}{lll}
\hline Treatment & fresh weight & dry weitht \\
\hline CK & $5.53 \pm 1.25 \mathrm{a}$ & $1.12 \pm 0.81 \mathrm{a}$ \\
A & $4.329 \pm 1.35 \mathrm{~b}$ & $0.56 \pm 0.12 \mathrm{~b}$ \\
AS & $5.12 \pm 1.36 \mathrm{a}$ & $0.97 \pm 0.24 \mathrm{~b}$ \\
S & $5.67 \pm 1.28 \mathrm{a}$ & $1.23 \pm 0.59 \mathrm{a}$ \\
\hline
\end{tabular}

Table 3 The fresh weight and dry weight of ginseng shoots and ginseng roots after different treatments

\begin{tabular}{llllll}
\hline & \multicolumn{2}{l}{ ginseng shoots } & & \multicolumn{2}{l}{ ginseng roots } \\
\cline { 2 - 3 } Treatment & fresh weight & dry weitht & & fresh weight & root dry weight \\
\hline CK & $2.51 \pm 0.21 \mathrm{a}$ & $0.38 \pm 0.11 \mathrm{a}$ & & $3.02 \pm 1.21 \mathrm{~b}$ & $0.75 \pm 0.12 \mathrm{~b}$ \\
$\mathrm{~A}$ & $1.56 \pm 0.12 \mathrm{~d}$ & $0.20 \pm 0.02 \mathrm{~d}$ & & $2.57 \pm 0.89 \mathrm{~d}$ & $0.52 \pm 0.11 \mathrm{c}$ \\
$\mathrm{AS}$ & $2.23 \pm 0.25 \mathrm{c}$ & $0.26 \pm 0.13 \mathrm{c}$ & & $2.89 \pm 0.98 \mathrm{c}$ & $0.61 \pm 0.12 \mathrm{~b}$ \\
$\mathrm{~S}$ & $2.39 \pm 0.31 \mathrm{~b}$ & $0.35 \pm 0.13 \mathrm{~b}$ & & $3.28 \pm 1.02 \mathrm{a}$ & $0.79 \pm 0.19 \mathrm{a}$ \\
\hline
\end{tabular}

Different letters within a column indicates significant difference among treatments $p<0.05$

and the results of all treatments were analyzed using a one-way ANOVA (Table 5). The coverage index of the sample library was more than $98.5 \%$, which indicated that the sequencing results represented the real situation of the bacterial population in the sample. The microflora richness index (Chao1, ACE) and biodiversity index (Shannon, Simpson) of the samples revealed that the diversity of the bacterial populations in the soil samples was relatively high (Table 5). Further analysis revealed that at a 97\% similarity level, the Shannon index and Simpson index of soil bacteria of each treatment group were not significantly different from those in the Control group.

\section{Analysis of soil bacterial community structure}

According to the abundance of bacterial OTU types in the 12 soil samples, a non-metric multidimensional scale (NMDS) diversity analysis was conducted to determine the differences in the bacterial compositions of the different samples and treatments (Fig. 2). The NMDS results were evaluated using the UniFrac distances to estimate the phylogenetic relatedness among the bacterial communities (Fig. 3a, c). The soil bacterial communities were found to be totally distinct between groups $\mathrm{A}$ and $\mathrm{S}$, i.e., when treated with $A$. panax or Si (NMDS). Among treatment groups, the soil bacterial composition of group Control was most similar to that of group AS, i.e., had the highest phylogenetic relatedness, and the group AS bacterial flora could be independently distinguished from that in the infected soil (group A). However, the composition of bacterial flora in group $S$ differed from that of the other treatments. In summary, $\mathrm{Si}$ application significantly regulated the changes in bacterial flora (back to the composition of Control) that were induced by inoculation of ginseng black spot (group AS).

\section{Cluster analysis of soil bacterial community structure}

Based on a Beta diversity analysis, a distance matrix was obtained for the 12 soil samples, and a hierarchical clustering analysis was conducted using the unweighted group average method (UPGMA) (Fig. 3b, d). The soil 
Table 4 Characteristics of soils after different treatments

\begin{tabular}{lllll}
\hline Indexes & CK & A & AS & S \\
\hline $\mathrm{pH}$ & $7.39 \pm 0.12 \mathrm{ab}$ & $7.05 \pm 0.24 \mathrm{c}$ & $7.39 \pm 0.26 \mathrm{a}$ & $7.38 \pm 0.36 \mathrm{~b}$ \\
Available phosphorus AP $(\mathrm{mg} / \mathrm{kg})$ & $13.15 \pm 2.61 \mathrm{ab}$ & $14.95 \pm 3.25 \mathrm{a}$ & $12.25 \pm 2.68 \mathrm{~b}$ & $12.73 \pm 2.62 \mathrm{~b}$ \\
Available potassium AK $(\mathrm{mg} / \mathrm{kg})$ & $194.48 \pm 3.26 \mathrm{~b}$ & $217.15 \pm 2.35 \mathrm{a}$ & $187.64 \pm 3.69 \mathrm{~b}$ & $199.06 \pm 2.65 \mathrm{~b}$ \\
Ammonium nitrogen $\mathrm{NH}_{4(\mathrm{~g} / \mathrm{kg})}$ & $16.42 \pm 2.35 \mathrm{a}$ & $4.58 \pm 1.02 \mathrm{c}$ & $9.38 \pm 2.36 \mathrm{~b}$ & $14.38 \pm 1.25 \mathrm{a}$ \\
Nitrate nitrogen $\mathrm{NO}_{3(\mathrm{~g} / \mathrm{kg})}$ & $1.31 \pm 0.25$ & $1.15 \pm 0.36$ & $1.89 \pm 0.28$ & $1.97 \pm 0.69$ \\
Available silicon ASi $(\mathrm{mg} / \mathrm{kg})$ & $457.99 \pm 20.35 \mathrm{~b}$ & $451.78 \pm 25.69 \mathrm{~b}$ & $457.02 \pm 19.89 \mathrm{~b}$ & $492.06 \pm 26.98 \mathrm{a}$
\end{tabular}

Different letters within a column indicates significant difference among treatments $p<0.05$

samples of groups $\mathrm{S}$ and AS were classified as one branch, and those of groups Control and AS group were classified as one branch. The results were consistent with those of the NMDS analysis, which fully demonstrated that the soils inoculated with $\mathrm{Si}$ + ginseng black spot (AS group) were significantly recovered compared with the soils inoculated with only ginseng black spot (S group). PLS-DA analysis showed that the microbial composition of soil in the AS group was significantly altered following Si treatment. The results suggested similarities between group Control and AS, but not with nor among the other two groups. In summary, Si was again shown to have alleviated the changes in soil bacteria caused by ginseng black spot (Fig. 4).

\section{Heat map analysis of the soil bacterial community structure}

A heat map of the bacterial community structure among different samples (Fig. 5) revealed the relative abundances of the various bacterial groups (at phylum and genus levels) and that significant differences were observed among different groups of samples. The results showed that, at the phylum level, Proteobacteria, Nitrospirae, Actinobacteria, and Bacteroidetes were the four main groups (Fig. 5). The relative abundances (represented by the color depth in Fig. 5) of Sandaracinus, Polycyclovorans, Hirschia, Bdellovibrio, Haliangium, and Nitrospira were significantly higher in group Control than those of group A $(P<0.05)$. In addition, the relative abundances of Sandaracinus, Polycyclovorans, Hirschia, Haliangium, and Nitrospira in group AS were significantly higher than those in $\mathrm{A}(\mathrm{P}<0.05)$. The results showed that $\mathrm{Si}$ application significantly regulated the structural impact of soil microorganisms caused by ginseng black spot inoculation.

\section{Factors influencing the quantity and composition of soil bacteria}

Correlation analysis showed (Table 6) that most of the other dominant bacterial groups had significant correlations with soil chemical properties, except Arenimonas, $H 16$, and RB41, which showed no correlations with all chemical indicators. Haliangium and available $\mathrm{K}$ were significantly negatively correlated; Phenylobacterium (phenyl coli) was very significantly negatively correlated with $\mathrm{pH}$ and Gemmatimonas (bacillus); Nitrospira (nitrification spirillum) was negatively correlated with $\mathrm{NO}_{3}{ }^{-}-\mathrm{N}$; Mesorhizobium (rhizobia) was very significantly positively correlated with $\mathrm{NO}_{3}{ }^{-}-\mathrm{N}$; Gemmatimonas (bacillus), Nitrospira (nitrobacteria), and available $\mathrm{Si}$ were significantly negatively correlated; Lactobacillus (lactobacillus), Mesorhizobium (rhizobium), and available Si were significantly positively correlated. Haliangium was significantly positively correlated with $\mathrm{pH}$.

\section{Discussion}

\section{Silicon reduced disease incidence and disease index of} ginseng black spot

Si has been shown to effectively improve the mechanical and physiological capacities of plants and enhance plant resistance to overcome various biotic and abiotic stresses $[12,13]$. To examine the effect of Si application on ginseng black spot-infected plants, a pot experiment was performed with pretreatment of Si for 2 weeks, following 9 dpi with A. panax. Si application significantly reduced the disease incidence and index of ginseng black spot

Table 5 The bacterial diversity indices of ginseng rhizosphere soil samples with different treatment

\begin{tabular}{llllllll}
\hline & Sequence number & OTU & $\begin{array}{l}\text { Coverage } \\
\%\end{array}$ & Shannon & Simpson & ACE & Chao1 \\
\hline CK & 207,437 & 7381 & 98.6 & $11.2 \pm 0.2$ & $0.9989 \pm 0.01$ & $5250.6 \pm 23.6 \mathrm{a}$ & $5149.3 \pm 123.3 \mathrm{a}$ \\
A & 209,093 & 7210 & 98.6 & $11.1 \pm 0.3$ & $0.9989 \pm 0.02$ & $5048.9 \pm 69.7 \mathrm{~b}$ & $5007.6 \pm 369.9 \mathrm{~b}$ \\
AS & 206,227 & 6974 & 98.5 & $11.1 \pm 0.2$ & $0.9988 \pm 0.01$ & $5138.2 \pm 102.3 \mathrm{a}$ & $5063.6 \pm 325.3 \mathrm{~b}$ \\
S & 192,852 & 7063 & 98.5 & $11.1 \pm 0.1$ & $0.9988 \pm 0.02$ & $5141.5 \pm 69.8 \mathrm{a}$ & $5163.2 \pm 345.6 \mathrm{a}$ \\
\hline
\end{tabular}

Different letters within a column indicates significant difference among treatments $p<0.05$ 


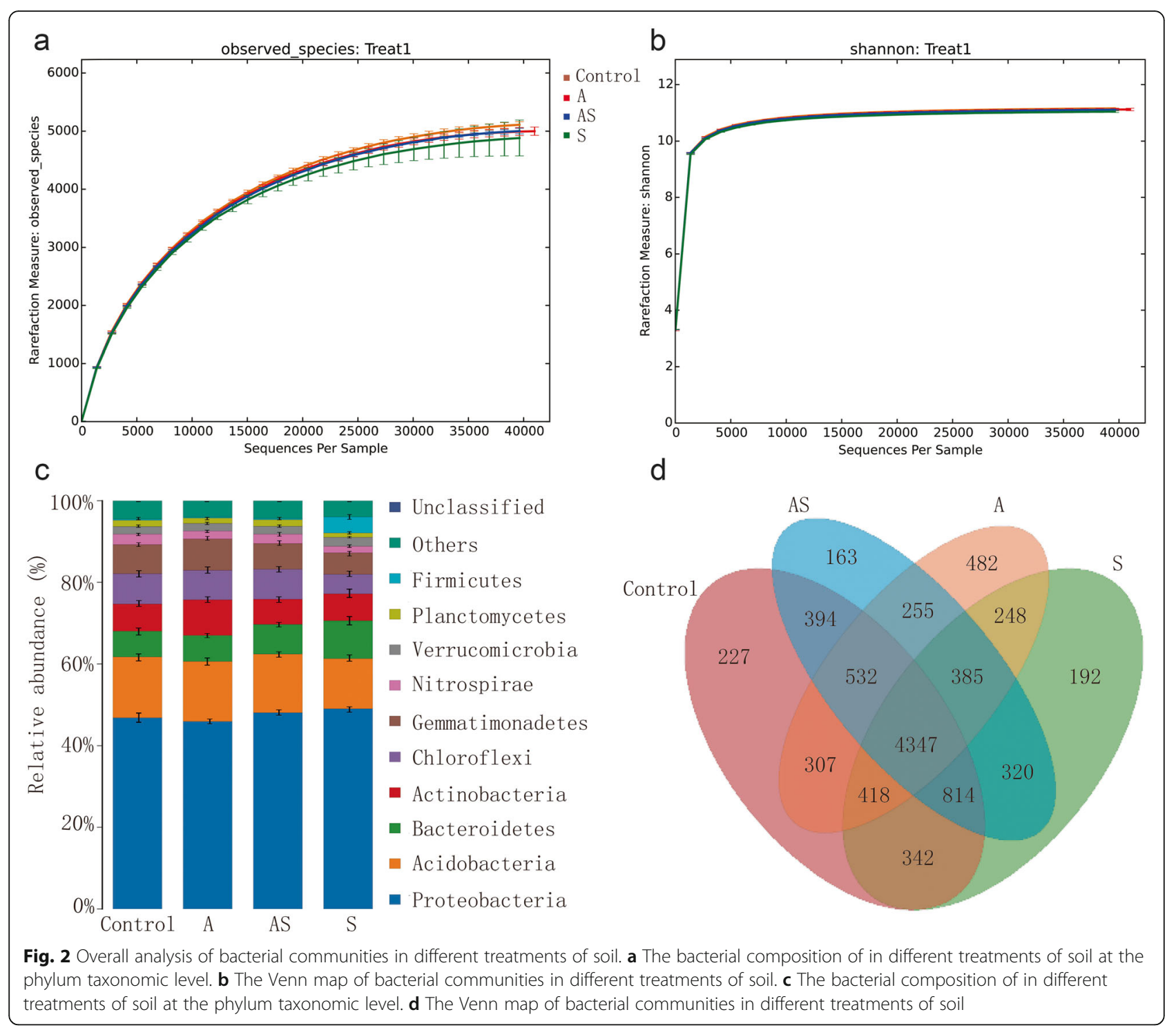

(Table 1) and clearly alleviated the incidence of leaf blight caused by A. panax (Fig. 1). Similarly, Si has been reported to enhance plant resistance to diseases, potentially through interacts with several key factors of the stress signaling pathway [14]. In comparison to group A plants, Si application was shown to increase the accumulation of shoot and root biomass in group AS P. ginseng plants. These findings suggest that $\mathrm{Si}$ triggered plant-microbial response mechanisms that directly limited ginseng black spot index and incidence in the leaves and thus enhanced $P$. ginseng biomass accumulation. However, the root and shoot biomass of group $\mathrm{S}$ plants was not significantly different compared with Control, which opposes the notion that $\mathrm{Si}$ promotes plant biomass accumulation [15-17]. In the present study, a short-term pot experiment was used to determine the effects of $\mathrm{Si}$ application on ginseng black spot and the soil bacterial community, however, future research is needed to clarify the effects of long-term applications on Si-P. ginseng-soil interactions.

\section{Soil properties}

Compared with the Control, inoculation of ginseng black spot (in group A) significantly reduced the soil $\mathrm{pH}$ and $\mathrm{NH}_{4}{ }^{+}-\mathrm{N}$ content, and significantly increased the ratio of available $\mathrm{K}$. After $\mathrm{Si}$ application, the reduced soil $\mathrm{pH}$ and $\mathrm{NH}_{4}{ }^{+}-\mathrm{N}$ content were significantly recovered to the levels of group Control. Compared with group $\mathrm{A}$, the ratio of available $\mathrm{P}$ and available $\mathrm{K}$ was reduced in group AS, which resulted in similar soil physical and chemical indexes to that of group CK. In the present study, Si application led to the amendment of the soil $\mathrm{pH}$ changes caused by the inoculation of ginseng black spot. However, the soil $\mathrm{pH}$ of group Control and group $\mathrm{S}$ were not significantly different, and thus $\mathrm{Si}$ application alone did not alter the $\mathrm{pH}$. A similar 


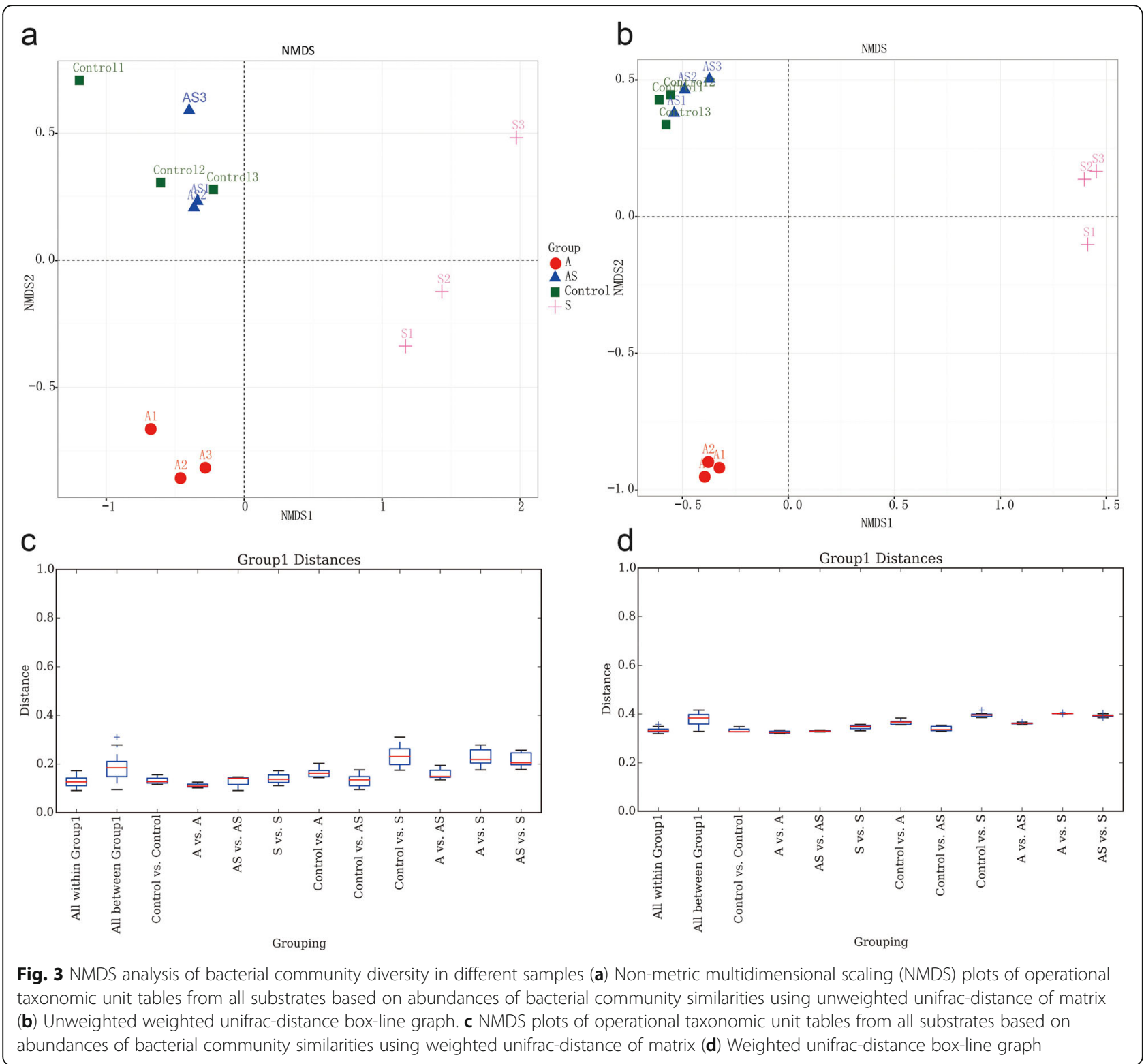

result was found in a study with $P$. notoginseng, whereby $\mathrm{Si}$ increased the soil $\mathrm{pH}$ when in the presence of arsenic, which may have been because the Si treatment decreased the bioavailability of arsenic [11]. Although our study does rule out the possibility of other chemical differences among treatments, our data doe does suggest that nutrient availabilities were not the driving differences in soil properties without pathogen inoculation. It is important to consider plant root exudates and their great impact on the population and community structure of soil microbes [18]. In our study, Si application may have affected the root exudates, and other root-derived molecules; as was observed in another study when plants were infected by a fungus [19]. Further research is needed to elucidate the root exudates$\mathrm{Si}$, plants-Si, and root exudates-plants interactions in the
soil-P. ginseng system. However, besides available $\mathrm{Si}$, there were no significant differences in the above-mentioned nutrients between groups $\mathrm{S}$ and Control. Therefore, it is likely that $\mathrm{Si}$ altered the root exudes rather than physicochemical soil characteristics, which caused the recovery of the bacterial community from A to AS, which was similar to Control.

\section{Soil microbial community composition and diversity}

Microbial community diversity is an important component of soil health [20]. The impact of $\mathrm{Si}$ on bacterial richness and diversity was analyzed by high-throughput sequencing. The soil bacterial richness (Shannon index and Simpson index) was not significantly different under the different treatments (Fig. 2), which indicated that Si and $A$. panax treatments did not alter the number of 


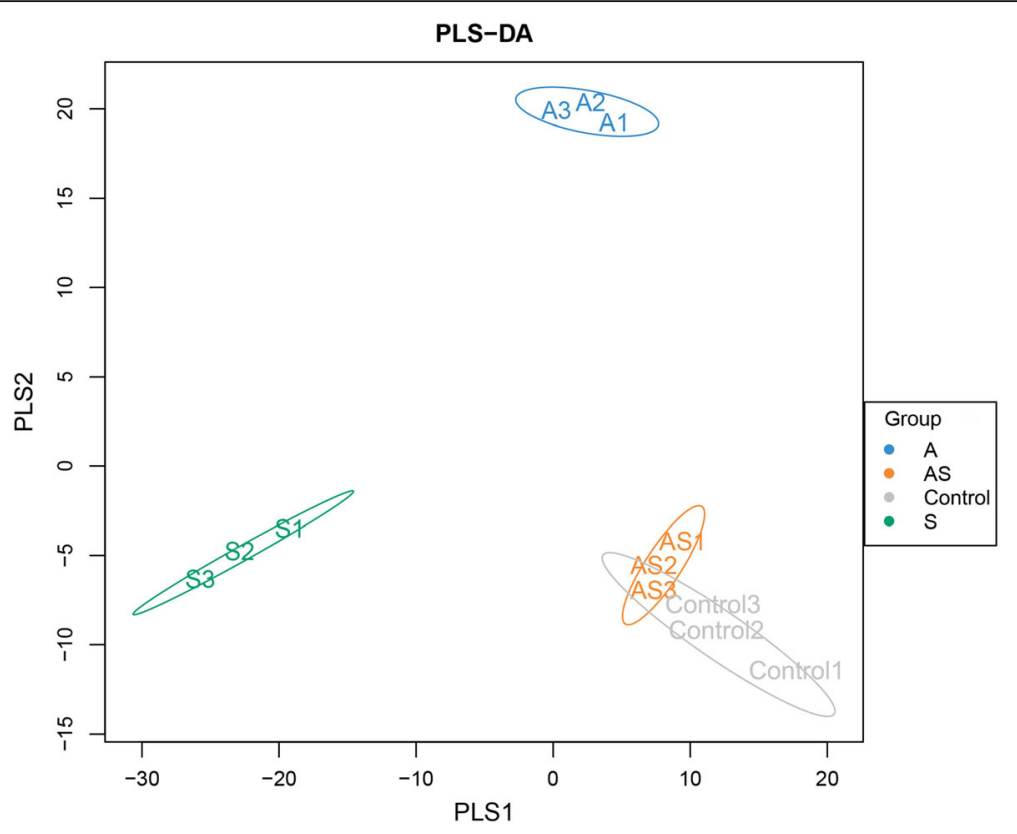

Fig. 4 PLS-DA analysis of different soil samples

bacterial species in the short-term. However, genes-level differences were found in the relative abundances of bacterial species. Interestingly, the relative abundances of Saccharothrix, Aeromicrobium, Luteimonas, and Rubellimicrobium recovered $(P<0.05)$ from lower levels in group A to higher levels (similar to Control) following $\mathrm{Si}$ application (Fig. 5). The results showed that Si application significantly regulated the structural impact of soil microorganisms caused by ginseng black spot. Aeromicrobium as a potential disease suppression indicator [21, 22] and a member of phylum Actinobacteria. Moreover, the antibiotics produced by Actinobacteria are able to suppress various plant diseases [23, 24]. Disease-suppressive natural soils, with reference to a variety of agricultural crop diseases, have been reported for wheat Take-all and Rhizoctonia bare patch diseases [25], Fusarium wilt on

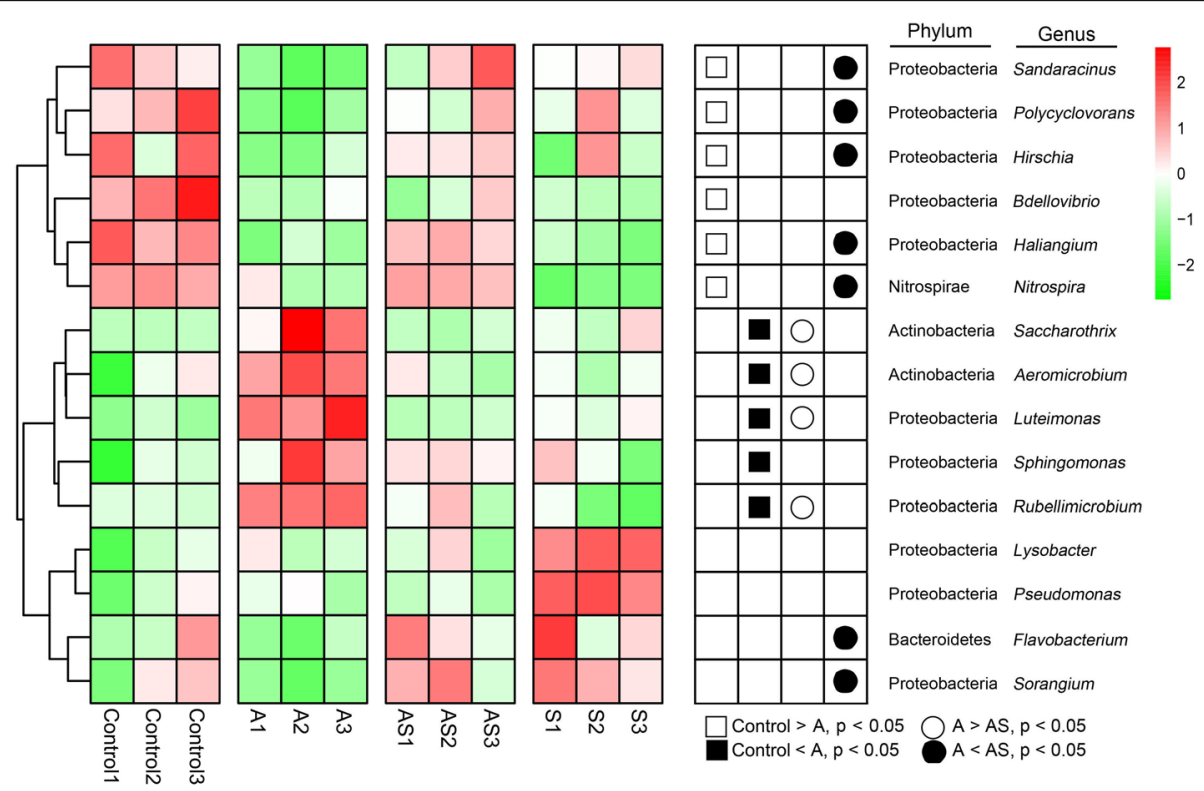

Fig. 5 Heat map comparison of the dominant bacterial with average relative abundance from blue to red means relative abundance from low to high 
Table 6 Pearson's correlation coefficients between various physicochemical variables and the relative abundances of main genera (>1\%) across all samples

\begin{tabular}{|c|c|c|c|c|c|c|}
\hline & $\mathrm{pH}$ & AP & AK & $\mathrm{NH}_{4}^{+}-\mathrm{N}$ & $\mathrm{NO}_{3}{ }^{-}-\mathrm{N}$ & $\mathrm{ASi}$ \\
\hline Arenimonas & 0.21 & -0.33 & -0.21 & -0.03 & 0.57 & 0.50 \\
\hline Gemmatimonas & -0.40 & 0.27 & 0.41 & 0.05 & $-0.66^{*}$ & $-0.62^{*}$ \\
\hline H16 (Proteobacteria) & 0.3 & 0.01 & -0.19 & 0.50 & -0.38 & -0.23 \\
\hline Haliangium & $0.65^{*}$ & -0.21 & $-0.67^{*}$ & 0.50 & -0.45 & -0.27 \\
\hline Lactobacillus & 0.13 & -0.37 & -0.01 & 0.09 & $0.96^{* *}$ & $0.92^{* *}$ \\
\hline Mesorhizobium & -0.01 & -0.36 & 0.01 & 0.05 & $0.80^{* *}$ & $0.84^{* *}$ \\
\hline Nitrospira & 0.48 & -0.02 & 0.51 & 0.26 & $-0.69^{*}$ & $-0.61 *$ \\
\hline Phenylobacterium & $-0.72^{* *}$ & 0.42 & $0.72^{* *}$ & -0.07 & 0.04 & 0.03 \\
\hline RB41 (Acidobacteria) & 0.04 & 0.10 & 0.11 & 0.06 & $\mathrm{NO}_{3}{ }^{-}-\mathrm{N}$ & -0.29 \\
\hline
\end{tabular}

Values in bold indicate significant correlations at ${ }^{* *} p<0.01$ and ${ }^{*} p<0.05$

strawberry and vanilla [26], and Rhizoctonia solani on sugar beet [27]. This characteristic relates to the abundance of certain beneficial soil microbes [26, 27], which produce antimicrobial compounds that directly inhibit pathogens. In addition, indirect pathogen inhibition via induced systemic resistance (ISR) may occur, via the triggering of plant immune responses [28]. However, in the event of a severe disease outbreak, consecutive cropping cycles of the same species are stipulated for diseasesuppressive microbes to flourish. The proposed hypothesis suggests that, when invaded, certain favorable microbes are amplified and sustained in plants $[25,29,30]$. The bacterial composition of the group Control soil was similar to that of group AS (Si-treated), i.e., their compositions had the highest phylogenetic relatedness. The group AS bacterial flora differed from that of the group A, and the composition of bacterial flora in group $\mathrm{S}$ differed from that of the other treatments. The results showed that $\mathrm{Si}$ application significantly regulated the changes in bacterial flora caused by ginseng black spot inoculation, and increased the levels in group AS to almost the same as group Control. Recent reports additionally revealed that Arabidopsis plants can stimulate specific favorable microbes in the rhizosphere, even in natural soils [31]. Another validating instance was seen when a Xanthomonas sp., Stenotrophomonas sp., and Microbacterium sp. beneficial consortium was activated in the rhizosphere as part of the downy mildew Hyaloperonospora arabidopsidis induced foliar defense [19]. Furthermore, these strains, when isolated, collectively induced downy mildew resistance, when inoculated back into Arabidopsis; and interestingly, the resistance of a second plant population grown in the same soil was considerably amplified as a result of the downy mildew infection in the first population. These outcomes collectively suggested that beneficial microbes ensue from plant invasions, which in turn prompt a memory or "soil-borne legacy" that amplifies the next plant generation defenses against harmful pathogens [31-34]. The implication here is that $\mathrm{Si}$ triggered the soil bacterial community response, which might have directly regulated plant growth. In the present study, we observed that the bacterial community differed in group AS compared with group A, i.e., between $\mathrm{Si}$ and no Si treatments. Overall, the increase in the soil bacterial diversity after $\mathrm{Si}$ application may contribute to the suppression of ginseng black spot disease. The functionality of root exudates and other root-derived molecules, is indicated in this process [31, 32, 35-37]; albeit this hypothesis requires validation. The most recent research, however, also reports that plants secure favorable rhizosphere communities via the modification of plant exudation patterns, induced by exposure to aboveground pathogens, which subsequently benefits future plant generations [19].

In summary, Si can alter the structure and diversity of the soil microbial community by directly and indirectly affecting the growth of plants, and the altered soil microbial community can, in turn, affect the plants [38-40].

\section{Conclusion}

This study provided a detailed outline of the bacterial community compositions in $\mathrm{Si}$ applications inoculated with ginseng black spot using Illumina HiSeq sequencing. Si application of ginseng black spot-inoculated plants significantly optimized soil bacterial population structure, improved soil bacterial activity and diversity, and thus effectively prevented and controlled the occurrence of ginseng black spot. In addition, we speculated that $\mathrm{Si}$ indirectly altered the structure, composition, and abundance of the soil microbial community by directly altering the root exudates or inducing plant systemic resistance. In conclusion, the present study demonstrated the good application prospect of $\mathrm{Si}$ and that it is recommended for use as ginseng fertilizer for the prevention and treatment of ginseng black spot. 


\section{Methods}

\section{Experimental design}

Two-year-old fresh ginseng roots (Panax ginseng Meyer) were provided by dongdu ginseng technology development co., LTD in April 2017 and placed in sand at $23{ }^{\circ} \mathrm{C}$. After 6 days, the roots sprouted and were then washed with deionized water, and transplanted into PVC pots $(120 \times 180 \mathrm{~mm}$, diameter $\times$ height $)$ containing turfy soil (6 seedlings per pot). The ginseng seedlings were grown under greenhouse conditions: temperatures of $17-28{ }^{\circ} \mathrm{C}$, a relative humidity of $70 \% \sim 80 \%$, and a $14 \mathrm{~h}$ photoperiod. Before A. panax inoculation, half of the plants were pretreated for 2 weeks with potassium silicate $(\mathrm{pH}=7.0)$ as the $\mathrm{Si}$ source. After $\mathrm{Si}$ pretreatment, the plants were inoculated with conidia of the appropriate $A$. panax pathogen. The conidia of $A$. panax infecting $P$. ginseng were identified by PCR of the internal transcribed spacer (ITS) region generating 553 554 bp fragments and the glyceraldehyde 3-phosphate dehydrogenase (gpd) for 565 566 bp fragments, respectively. Sequence showed $100 \%$ identical to that of $A$. panax (JF417572 of ITS, JF417653 of gpd). The $A$. panax strain was deposited in the Culture Collection Center of Yangtze University in Jingzhou, China. Spores were flushed from colonies and then resuspended in sterile distilled water at $1 \times 10^{5}$ spores $/ \mathrm{mL}$. The sterilized surfaces of detached spring ginseng leaves were inoculated with $20 \mu \mathrm{L}$ conidial suspension and incubated under the same greenhouse conditions for 9 days, when black spot symptoms became visible on the leaves.

Plants were grown under four kinds of treatment: ginseng control plants (Control), plants only inoculated with $A$. panax (A), plants inoculated with $A$. panax $+\mathrm{Si}$ (AS), and plants only inoculated with $\mathrm{Si}$ (S), with 18 plants (3 pots) per treatment. To test the prophylactic role of $\mathrm{Si}$, the $\mathrm{Si}$ concentration was set at $1.7 \mathrm{mM}$, i.e., the highest possible concentration of silica acid in solution [4].

Six seedlings of ginseng were randomly selected from each treatment group, and the soils were mixed to form a single representative sample. After inoculation with $A$. panax for 9 days, plants were removed from the soil and the excess soil was carefully shaken off. The rhizosphere soil (i.e., adhering to the roots) was collected as previously described by Bulgarelli et al. [41], with some modifications. Three replicate rhizosphere soil samples were obtained per treatment. Soil samples $(n=12)$ were air-dried for 2 weeks, passed through a $2 \mathrm{~mm}$ sieve, and stored at $80^{\circ} \mathrm{C}$.

\section{Plant dry weights and analysis of disease index and incidence}

For $A$. panax infected plants, ginseng black spot incidence was recorded from 9 days after $A$. panax inoculation. The
18 plants (3 pots) per treatment were collected to calculate the percentage of diseased plants and count disease index, using the following equations [42]:

$$
\begin{aligned}
\text { Disease incidence }= & \text { the number of diseased plants } / \\
& \text { the total number of plants } \times 100 \%
\end{aligned}
$$

$$
\text { Disease index }=\sum(A \times B) \times 100 / \sum \times 4
$$

where $\mathrm{A}$ is the disease class $(0,1,2,3,4)$ and $\mathrm{B}$ is the number of plants in the corresponding disease class.

For each plant, the shoots and roots were separated and weighed after air drying (dry weight, g) for 2 weeks at $30^{\circ} \mathrm{C}$.

\section{Sampling and chemical analysis}

Air-dried plants and soil samples were used in the nutrient analysis. About $50 \mathrm{mg}$ oven-dried plant tissue was digested with a mixture of $8 \mathrm{~mL} \mathrm{HNO}_{3}$ and $2 \mathrm{~mL} \mathrm{HClO}_{4}$ at $200{ }^{\circ} \mathrm{C}$ for $120 \mathrm{~min}$ in a semi-closed system. The digestates were cooled down to $25^{\circ} \mathrm{C}$ and made up to $50 \mathrm{~mL}$ with $4 \%(\mathrm{v} / \mathrm{v}) \mathrm{HNO}_{3}$ solution. The soil $\mathrm{pH}(1: 5$, soil: water) was measured using a glass electrode (SK220, Switzerland). Soil nitrate nitrogen $\left(\mathrm{NO}_{3}{ }^{-} \mathrm{-N}\right)$ was assayed using a continuous flow analytical system (SJAKAR $\mathrm{SAN}^{++}$, The Netherlands). Ammonium nitrogen $\left(\mathrm{NH}_{4}{ }^{+}-\right.$ $\mathrm{N}$ ) in the soil was extracted with $0.01 \mathrm{M} \mathrm{CaCl}_{2}$, and the concentration was measured by an Auto Analyzer (Auto Analyzer 3, Germany). Potassium (K) in the soil was dissolved with ammonium acetate and calculated by flame photometry. Soluble phosphorus (P) was dissolved with sodium bicarbonate and its concentration measured using the molybdenum blue method [43].

\section{High-throughput sequencing}

The total DNA was extracted from $0.5 \mathrm{~g}$ of each soil sample using a bacterial DNA Isolation Kit (Omega Bio-tek, Norcross, GA, USA) following the manufacturer's instructions [44]. To assess the bacterial community composition, Illumina HiSeq platform (Illumina, San Diego, California, USA) was used in present study. The quantity and quality of extracted DNAs were measured using a Nanodrop 1000 (Thermo Fisher Scientific, Wilmington, DE, USA) and agarose gel electrophoresis, respectively. Primers for amplification and preamplification sequence: bacterial 16S rRNA gene V3-V4 region primers: 338F (5'ACTCCTACGGGAGGCAGCA-3') and 806R (5'-GGAC TACHVGGGTWTCTAAT-3'). DNA was amplified by PCR under conditions of $95^{\circ} \mathrm{C} 2 \mathrm{~min}$, followed by $27 \mathrm{cy}$ cles of $95^{\circ} \mathrm{C}$ extends $30 \mathrm{~s}, 55^{\circ} \mathrm{C}$ for $30 \mathrm{~s}$ and $72{ }^{\circ} \mathrm{C}$ for $45 \mathrm{~s}$; and a final extension at $72{ }^{\circ} \mathrm{C}$ for $10 \mathrm{~min}$, then maintained at $10^{\circ} \mathrm{C}$ until halted. The PCR reactions were performed triplicate in a $20 \mu \mathrm{L}$ mixture contained $4 \mu \mathrm{L} 5 \mathrm{Mix} \times$ FastPfu Buffffer, $2 \mu \mathrm{L}$ of $2.5 \mathrm{mM}$ dNTPs, $0.4 \mu \mathrm{L}$ of each primer $(5 \mu \mathrm{M}), \quad 0.4 \mu \mathrm{L}$ of TransStart FastPfu DNA 
Polymerase (TransGen Biotech, Beijing, China), and $10 \mathrm{ng}$ of template DNA [45]. PCR amplicons were purified with A gencourt AMPure Beads (Beckman Coulter, Indianapolis, IN) and quantified using the PicoGreen dsDNA Assay Kit (Invitrogen, Carlsbad, CA, USA). After the individual quantification step, amplicons were pooled in equal amounts, and pair-end $2 \times 300 \mathrm{bp}$ sequencing was performed using the Illumina HiSeq platform (Illumina, San Diego, California, USA) at Biomarker Technologies, Beijing, China.

The Quantitative Insights Into Microbial Ecology (QIIME, v1.8.0) pipeline was employed to process the sequencing data [46]. The low-quality sequences were filtered through the criteria [47, 48]. Paired-end reads were assembled using FLASH [49]. After chimera detection, the remaining high-quality sequences were clustered into operational taxonomic units (OTUs) at 97\% sequence identity by UCLUST [50]. A representative sequence was selected from each OTU using default parameters. OTU taxonomic classification was conducted by BLAST searching the representative sequences set against the Greengenes Database [51]. Each OUT in each sample and the taxonomy was recorded in an OTU table, and OTUs containing less than $0.001 \%$ of total sequences across all samples were discarded. Sequences were deposited at the NCBI Short Read Archive and accession numbers are SRR9822023-SRR9822034.

Sequence data analyses were mainly performed using QIIME and R packages (v3.2.0). OTU-level alpha diversity indices, were calculated in QIIME. Beta diversity analysis was performed to investigate the structural variation of microbial communities across samples using UniFrac distance metrics $[52,53]$ and nonmetric multidimensional scaling (NMDS) [54]. Venn diagram was generated to visualize the shared and unique OTUs among groups using $\mathrm{R}$ package [55]. Taxa abundances at the phylum, class, order, family, genus and species levels were statistically compared among groups by Metastats [56]. PLS-DA (Partial least squares discriminant analysis) was also introduced as a supervised model to reveal the microbiota variation among groups, using the "plsda" function in R package "mixOmics" [48].

\section{Data analysis}

One-way analysis of variance (ANOVA) was used to calculate the difference between treatments with variable soil pathogen abundance. The significance threshold was set at 0.05 . The statistical analyses was performed using SAS 9.1 software (SAS Institute Inc., Cary, NC).

\section{Abbreviations}

ANOVA: Analysis of variance; dpi: Days after post inoculation; gpd: Glyceraldehyde 3-phosphate dehydrogenase; ITS: Internal transcribed spacer; NMDS: Non-metric multidimensional scale; OTU: Operational taxonomic unit; PLS-DA: Partial least squares discriminant analysis; Si: Silicon; UPGMA: Unweighted group average method

\section{Acknowledgements}

We thank Jianxin Deng (Yangtze University) for constructive input and discussions. We also acknowledge Hai Sun for Biotechnology, for providing the necessary facilities. YZ acknowledges Cai Shao and Yiming Guan for assistance in seedling and sample collection.

\section{Authors' contributions}

ML carried out the experimental plan, collected samples. QW, ZL and XP extracted DNA and conducted data analysis. YZ participated in the experimental design, and drafted the manuscript. All authors read and approved the final manuscript.

\section{Funding}

YZ acknowledges funding from China Agriculture Research System (CARS-21), the Agricultural Science and Technology Innovation Program (CAAS-XTCX2016012), National Key R\&D Program of China (2018YFD0201100), Collaborative innovation project of science and technology innovation project of Chinese academy of agricultural sciences (2018XTCX01), the National Natural Science Foundation of China (31501828), the National Natural Science Foundation of China (81903755), and the Central Public-interest Scientific Institution Basal Research Foundation of CAAS (No. 1610342017017, No. 1610342018011, No. 1610342018020) on highthroughput sequencing. The funding body had no role in the design of the study, analysis and interpretation of data and in writing the manuscript.

\section{Availability of data and materials}

The dataset(s) supporting the conclusions of this article are available in the following repositories: The raw read sequences were deposited at the NCBI Short Read Archive and accession numbers are SRR9822023-SRR9822034.

Ethics approval and consent to participate

Not applicable.

\section{Consent for publication}

Not applicable.

\section{Competing interests}

The authors declare that they have no competing interests.

Received: 12 July 2019 Accepted: 28 October 2019

Published online: 26 November 2019

References

1. Putnam ML, Toit LJD. First report of alternaria blight caused by Alternaria panax on ginseng (Panax quinquefolius) in Oregon and Washington, USA. [J]. Plant Pathol 2010; 52(3):406-406. https://doi.org/10.1046/j.1365-3059. 2003.00828x

2. Epstein E. Silicon. Ann. Rev. Plant Physiol Plant Mol Biol. 1999:50:641-64 https://doi.org/10.1146/annurev.arplant.50.1.641.

3. Fauteux F, Remus-Borel W, Menzies JG, Belanger RR. Silicon and plant disease resistance against pathogenic fungi. FEMS Microbiol Lett. 2005;249: 1-6 https://doi.org/10.1016/j.femsle.2005.06.034.

4. Vivancos J, Labbé C, Menzies JG, Bélanger RR. Silicon-mediated resistance of Arabidopsis against powdery mildew involves mechanisms other than the salicylic acid (SA)-dependent defence pathway. Mol Plant Pathol. 2015;16: 572-82 https://doi.org/10.1111/mpp.12213.

5. Aliyeh R, Caroline L, Humira S, et al. Silicon protects soybean plants against Phytophthora sojae by interfering with effector-receptor expression. BMC Plant Biol. 2018;18(1):97 https://doi.org/10.1186/s12870-018-1312-7.

6. Nayyar A, Hamel C, Lafond G, Gossen BD, Hanson K, Germida J. Soil microbial quality associated with yield reduction in continuous-pea. Appl Soil Ecol. 2009;43(1):115-21 https://doi.org/10.1016/j.apsoil.2009.06.008.

7. Liu X, Zhang S, Jiang Q, Bai Y, Shen G, Li S, Ding W. Using community analysis to explore bacterial indicators for disease suppression of tobacco bacterial wilt. Sci Rep 2016;6:36773. https://doi.org/https://doi.org/10.1038/ srep36773.

8. Fang $S$, Liu D, Ye T, Deng $S$, Shang $X$. Tree species composition influences enzyme activities and microbial biomass in the Rhizosphere: a Rhizobox 
approach. PLoS One. 2013;8(4):e61461 https://doi.org/10.1371/journal.pone. 0061461.

9. Cai K, Gao D, Luo S, Zeng R, Yang J, Zhu X. Physiological and cytological mechanisms of silicon-induced resistance in rice against blast disease. Physiol Plant 2008;134(2):324-333. https://doi.org/https://doi.org/10.1111/j. 1399-3054.2008.01140.x.

10. Ghareeb H, Bozsó Z, Ott PG, Repenning C, Stahl F, Wydra K. Transcriptome of silicon-induced resistance against Ralstonia solanacearum in the silicon non-accumulator tomato implicates priming effect. Physiol Mol Plant Pathol. 2011;75(3):83-9 https://doi.org/10.1016/j.pmpp.2010.11.004.

11. Yue Y, Aichen Z, Yanjiao C, et al. Impacts of silicon addition on arsenic fractionation in soils and arsenic speciation in Panax notoginseng planted in soils contaminated with high levels of arsenic. Ecotox Environ Safe. 2018; 162:400-7 https://doi.org/10.1016/j.ecoenv.2018.07.015.

12. Richmond KE, Sussman M. Got silicon? The non-essential beneficial plant nutrient. Curr Opin Plant Biol 2003;6(3):268-272. https://doi.org/10.1016/ s1369-5266(03)00041-4

13. Ma JF, Yamaji N. Silicon uptake and accumulation in higher plants. Trends Plant Sci. 2006;11:392-7 https://doi.org/10.1016/j.tplants.2006.06.007.

14. Fawe A, Abou-Zaid M, Menzies JG, Bélanger RR. Silicon-mediated accumulation of flavonoid phytoalexins in cucumber. Phytopathology. 1998; 88:396-401 https://doi.org/10.1094/PHYTO.1998.88.5.396.

15. Fleck AT, Mattusch J, Schenk MK. Silicon decreases the arsenic level in rice grain by limiting arsenite transport. J Plant Nutr Soil Sci. 2013;176:785-94 https://doi.org/10.1002./jpln.201200440.

16. Li RY, Stroud JL, Ma JF, Mcgrath SP, Zhao FJ. Mitigation of arsenic accumulation in rice with water management and silicon fertilization. Environ Sci Technol. 2009;43:3778-83 https://doi.org/10.1021/es803643v.

17. Wu C, Zou Q, Xue S, Pan W, Yue X, Hartley W, Huang L, Mo J. Effect of silicate on arsenic fractionation in soils and its accumulation in rice plants. Chemosphere. 2016;165:478-86 https://doi.org/10.1016/j.chemosphere.2016. 09.061.

18. Kong HG, Kim BK, Song GC, Lee S, Ryu C-M. Aboveground whitefly infestation-mediated reshaping of the root microbiota. Front Microbiol. 2016;7:1314 https://doi.org/10.3389/fmicb.2016.01314.

19. Jun Y, Jun Z, Tao W, et al. Root exudates drive the soil-borne legacy of aboveground pathogen infection. Microbiome. 2018;6(1):156 https://doi.org/ 10.1186/s40168-018-0537-x.

20. Garbeva P, Van Veen JA, Van Elsas JD. Microbial diversity in soil: selection of microbial populations by plant and soil type and implications for disease suppressivenss. Annu Rev Phytopathol. 2004;42:243-70 https://doi.org/10. 1146/annurev.phyto.42.012604.135455.

21. Palaniyandi SA, Yang SH, Zhang L, Suh JW. Effects of actinobacteria on plant disease suppression and growth promotion. Appl Microbiol Biotechnol. 2013;97:9621-36 https://doi.org/10.1007/s00253-013-5206-1.

22. Shen G, Zhang S, Liu X, Jiang Q, Ding W. Soil acidification amendments change the rhizosphere bacterial community of tobacco in a bacterial wilt affected field. Appl Microbiol Biotech. 2018;102(22):9781-91 https://doi.org/ 10.1007/s00253-018-9347-0

23. Kim YS, Kim HM, Chang C, Hwang IC, Oh H, Ahn JS, Kim KD, Hwang BK, Kim BS. Biological evaluation of neopeptins isolated from a Streptomyces strain. Pest Manag Sci. 2007;63:1208-14 https://doi.org/10.1002/ps.1450.

24. Lee SY, Tindwa H, Lee YS, Naing KW, Hong SH, Nam Y, Kim KY. Biocontrol of anthracnose in pepper using chitinase, $\beta-1,3$ glucanase, and 2furancarboxaldehyde produced by Streptomyces cavourensis SY224. J Microbiol Biotechnol. 2012;22:1359-66 https://doi.org/10.4014/jmb1203. 02056.

25. Weller DM, Raaijmakers JM, Gardener BB, Thomashow LS. Microbial populations responsible for specific soil suppressiveness to plant pathogens. Annu Rev Phytopathol. 2002;40:309-48 https://doi.org/10.1146/annurev. phyto.40.030402.110010.

26. Cha JY, Han S, Hong HJ, Cho H, Kim D, Kwon Y, Kwon SK, Crüsemann M, Bok Lee $Y$, Kim JF, et al. Microbial and biochemical basis of a Fusarium wiltsuppressive soil. ISME J. 2016;10:119-29 https://doi.org/10.1038/ismej.2015.95.

27. Mendes R, Kruijt K, De Bruijn I, Dekkers E, Van Der Voort M, Schneider JH, et al. Deciphering the rhizosphere microbiome for disease-suppressive bacteria. Science. 2011;332:1097-100 https://doi.org/10.1126/science. 1203980.

28. Pieterse CM, Van Der Does D, Zamioudis C, Leon-Reyes A, Van Wees SC. Hormonal modulation of plant immunity. Annu Rev Cell Dev Biol. 2012;28: 489-521 https://doi.org/10.1146/annurev-cellbio-092910-154055.
29. Berendsen RL, Pieterse CM, Bakker PA. The rhizosphere microbiome and plant health. Trends Plant Sci. 2012;17:478-86 https://doi.org/10.1016/j. tplants.2012.04.001.

30. Schlatter D, Kinkel L, Thomashow L, Weller D, Paulitz T. Disease suppressive soils: new insights from the soil microbiome. Phytopathology. 2017;107: 1284-97 https://doi.org/10.1094/PHYTO-03-17-0111-RVW.

31. Berendsen RL, Vismans G, Yu K, Song Y, de Jonge R, Burgman WP, Burmølle M, Herschend J, Bakker PAHM, Pieterse CMJ. Disease-induced assemblage of a plant-benefificial bacterial consortium. ISME J. 2018;12:1496-507 https:// doi.org/10.1038/s41396-018-0093-1.

32. Rudrappa T, Czymmek KJ, Pare PW, Bais HP. Root-secreted malic acid recruits beneficial soil bacteria. Plant Physiol. 2008;148:1547-56 https://doi. org/10.1104/pp.108.127613.

33. Raaijmakers JM, Mazzola M. Soil immune responses. Science. 2016;352:13923 https://doi.org/10.1126/science.aaf3252.

34. Bakker PAHM, Pieterse CMJ, de Jonge R, Berendsen RL. The soil-borne legacy. Cell. 2018;172:1178-80 https://doi.org/10.1016/j.cell.2018.02.024.

35. Badri DV, Chaparro JM, Zhang RF, Shen QR, Vivanco JM. Application of natural blends of phytochemicals derived from the root exudates of Arabidopsis to the soil reveal that phenolic-related compounds predominantly modulate the soil microbiome. J Biol Chem 2013;288:45024512. https://doi.org/10.1074/jbc. M112.433300.

36. Gu Y, Wei Z, Wang X, Friman V-P, Huang J, Wang X, Mei X, Xu Y, Shen $Q$, Jousset A. Pathogen invasion indirectly changes the composition of soil microbiome via shifts in root exudation profile. Biol Fertil Soils. 2016;52:9971005 https://doi.org/10.1007/s00374-016-1136-2.

37. Sasse J, Martinoia E, Northen T. Feed your friends: do plant exudates shape the root microbiome? Trends Plant Sci. 2018;23:25-41 https://doi.org/10. 1016/j/tplants.2017.09.003.

38. Kardol P, Martijn BT, Van Der Putten WH. Temporal variation in plant-soil feedback controls succession. Ecol Lett 2006; 9(9):1080-1088. https://doi. org/https://doi.org/10.1111/j.1461-0248.2006.00953.x.

39. Reinhart KO, Callaway RM. Soil biota and invasive plants. New Phytol. 2006; 170(3):445-57 https://doi.org/10.1111/j.1469-8137.2006.01715.x.

40. Bever JD, Dickie IA, Facelli E, Facelli JM, Klironomos J, Moora M. Rooting theories of plant community ecology in microbial interactions. Trends Ecology Evol 2010; 25(8):468-478. https://doi.org/https:/doi.org/10.1016/j.tree.2010.05.004.

41. Bulgarelli D, Rott M, Schlaeppi K, Ver Loren van Themaat E, Ahmadinejad N, Assenza F, Rauf P, Huettel B, Reinhardt R, Schmelzer E, et al. Revealing structure and assembly cues for Arabidopsis root-inhabiting bacterial microbiota. Nature. 2012;488(7409):91-95. https://doi.org/https://doi.org/10. 1038/nature11336.

42. Faheem M, Raza W, Zhong W, Nan Z, Shen Q, Xu Y. Evaluation of the biocontrol potential of streptomyces goshikiensis YCXU against Fusarium oxysporum f. sp. niveum: theory and applications in pest management. Biol Control. 2015;81 (10):101-10 https://doi.org/10.1016/j.biocontrol.2014.11.012.

43. Sun H, Wang Q, Liu N, Zhang C, Liu Z, Zhang Y. Effects of different leaf litters on the physicochemical properties and bacterial communities in Panax ginseng-growing soil. Appl Soil Ecol. 2016;111:17-24 https://doi.org/ 10.1016/j.apsoil.2016.11.008.

44. Zhang H, Feng J, Chen S, et al. Geographical patterns of nirS gene abundance and nirS-type denitrifying bacterial community associated with activated sludge from different wastewater treatment plants. Microb Ecol. 2019;77(2):304-16 https://doi.org/10.1007/s00248-018-1236-7.

45. Wang $\mathrm{Q}$, Sun $\mathrm{H}, \mathrm{Xu} \mathrm{C}$, et al. Analysis of rhizosphere bacterial and fungal communities associated with rusty root disease of Panax ginseng. Appli Soil Ecol. 2019;138:245-52 https://doi.org/10.1016/j.apsoil.2019.03.012.

46. Caporaso JG, Kuczynski J, Stombaugh K, Bittinger FD, Bushman EK, Costello $\mathrm{N}$, Fierer AG, Pena JK, Goodrich Jl, Gordon GA, et al. QIIME allows analysis of high-throughput community sequencing data. Nat Methods. 2010;7(5):3356 https://doi.org/10.1038/nmeth.f.303.

47. Gill SR, Pop M, DeBoy RT, Eckburg PB, Turnbaugh PJ, Samuel BS, Gordon Jl, Relman DA, Fraser-Liggett CM, Nelson KE. Metagenomic analysis of the human distal gut microbiome. Science. 2006;312(5778):1355-9 https://doi. org/10.1126/science.1124234.

48. Chen YF, Yang FL, Lu HF, Wang BH, Chen YB, Lei DJ, Wang YZ, Zhu BL, Li L. Characterization of fecal microbial communities in patients with liver cirrhosis. Hepatology. 2011;54(2):562-72 https://doi.org/10.1002/hep.24423.

49. Magoc T, Salzberg SL. Flash: fast length adjustment of short reads to improve genome assemblies. Bioinformatics. 2011;27(21):2957-2963. https:// doi.org/https://doi.org/10.1093/bioinformatics/btr507. 
50. Edgar RC. Search and clustering orders of magnitude faster than BLAST. Bioinformatics. 2010;26(19):2460-1 https://doi.org/10.1093/bioinformatics/ btq461.

51. DeSantis TZ, Hugenholtz P, Larsen N, Rojas M, Brodie EL, Keller K, Huber T, Dalevi D, Hu P, Andersen GL. Greengenes, a chimera-checked 165 rRNA gene database and workbench compatible with ARB. Appl Environ Microbiol. 2006;72(7):5069-72 https://doi.org/10.1128/AEM.03006-05.

52. Lozupone C, Knight R. UniFrac: a new phylogenetic method for comparing microbial communities. Appl Environ Microb. 2005;71(12):8228-35 https:// doi.org/10.1128/AEM.71.12.8228-8235.2005.

53. Lozupone CA, Hamady M, Kelley ST, Knight R. Quantitative and qualitative beta diversity measures lead to different insights into factors that structure microbial communities. Appl Environ Microb. 2007;73(5):1576-85 https://doi. org/10.1128/AEM.01996-06.

54. Ramette A. Multivariate analyses in microbial ecology. FEMS Microbio Ecol. 2007;62(2):142-60 https://doi.org/10.1111/j.1574-6941.2007.00375.x.

55. Zaura E, Keijser BJF, Huse SM, Crielaard W. Defining the healthy "core microbiome" of oral microbial communities. BMC Microbiol. 2009;9:12 https://doi.org/10.1186/1471-2180-9-259.

56. White JR, Nagarajan N, Pop M. Statistical methods for detecting differentially abundant features in clinical metagenomic samples. PloS Comput Biol. 2009;5(4) https://doi.org/10.1371/journal.pcbi.1000352.

\section{Publisher's Note}

Springer Nature remains neutral with regard to jurisdictional claims in published maps and institutional affiliations.

Ready to submit your research? Choose BMC and benefit from:

- fast, convenient online submission

- thorough peer review by experienced researchers in your field

- rapid publication on acceptance

- support for research data, including large and complex data types

- gold Open Access which fosters wider collaboration and increased citations

- maximum visibility for your research: over $100 \mathrm{M}$ website views per year

At $\mathrm{BMC}$, research is always in progress.

Learn more biomedcentral.com/submissions 